\title{
Agronomic performance of okra under the effect of seed microbiolization with rhizobacteria
}

\author{
Wagner F Mota ${ }^{1}$; Gevaldo B Oliveira ${ }^{1}$; Sérgio AM Nobre²; Humberson R Silva ${ }^{3}$ \\ ${ }^{1}$ Universidade Estadual de Montes Claros, Depto. Ciências Agrárias (UNIMONTES), Janaúba-MG, Brasil; wagner.mota@unimontes.br; \\ gevaldo.oliveira@unimontes.br; ${ }^{2}$ Universidade Estadual de Montes Claros, Depto. de Biologia Geral (UNIMONTES), Montes Claros-MG, \\ Brasil; sergio.nobre@unimontes.br; ${ }^{3}$ Universidade Federal de Lavras, Depto. Fitopatologia (UFLA), Lavras-MG, Brasil; umbersonagronomo@ \\ yahoo.com.br
}

\section{ABSTRACT}

Plant-growth promoting rhizobacteria are an alternative to increase the productivity, adding value to the productive system of crops like okra. We aimed to evaluate the agronomic characteristics of okra genotypes after seed microbiolization with nine strains of rhizobacteria. The experimental design was in randomized blocks, in a $2 \times 10$ factorial scheme, using two okra genotypes, cultivar Santa Cruz 47 and hybrid Dardo, nine strains of rhizobacteria, LEBM 103, $105,109,112,118,134,135,152$ and 154 and one control (without microbiolization), with four replications. We analyzed number of fruits per plant (NFP), average diameter of fruits (DM), productivity (PDT); fresh mass of fruits per plant (MFFP) and average mass of fruit (MMF). The rhizobacteria strains LEBM 109, 112, 152 and 154 provided the highest values for MFFP $(1202.7 ; 1086.5 ; 1158.2$ and $1175.9 \mathrm{~g}$, respectively) PDT $(24.1 ; 21.7 ; 23.2$ and $23.5 \mathrm{t} / \mathrm{ha}$, respectively) and NFP (78.0; 69.4; 73.27 and 76.5, respectively) in relation to the other strains and the non-use of seed microbiolization of hybrid Dardo. For cultivar Santa Cruz 47, the rhizobacteria LEBM 105,112 and 152 provided the highest values for $\operatorname{MFFP}(896.7 ; 769.0$ and $762.2 \mathrm{~g}$, respectively). Evaluating genotypes when using each rhizobacteria, for MFFP and PDT, only for LEBM 105, no difference among genotypes was noticed, so, we concluded that okra seed microbiolization with rhizobacteria may provide productivity gain with possibility to become a feasible technique. The rhizobacteria which are the most recommended for growing hybrid Dardo are LEBM 109, 112, 152 and 154, whereas for growing cultivar Santa Cruz 47 are LEBM 105, 112 and 152.

Keywords: Abelmoschus esculentus, rhizosphere microorganisms, okra genotypes.

\section{RESUMO}

Desempenho agronômico de cultivares de quiabeiro sob efeito da microbiolização das sementes com rizobactérias

As rizobácterias promotoras de crescimento de plantas surgem como alternativa para incrementar a produtividade, agregando valor ao sistema produtivo de culturas como o quiabeiro. Este trabalho objetivou avaliar o rendimento agronômico de duas cultivares de quiabeiro após a microbiolização das sementes com nove cepas de rizobactérias. O delineamento experimental utilizado foi em blocos inteiramente casualizados, em esquema fatorial 2x10, sendo dois genótipos de quiabo, cultivar Santa Cruz 47 e híbrido Dardo, nove cepas de rizobactéria, LEBM 103, 105, 109, 112, 118, 134, 135, 152 e 154, além de uma testemunha (sem microbiolização), com quatro repetições. As variáveis analisadas foram: número de frutos por planta (NFP); diâmetro médio dos frutos (DM); produtividade (PDT); massa fresca dos frutos por planta (MFFP) e massa média por fruto (MMF). Verificou-se que a utilização das rizobactérias LEBM 109, 112, 152 e 154 condicionou maiores valores de MFFP $(1202,7 ; 1086,5 ; 1158,2$ e $1175,9 \mathrm{~g}$, respectivamente), PDT $(24,1 ; 21,7 ; 23,2$ e $23,5 \mathrm{t} / \mathrm{ha}$, respectivamente) e NFP $(78,0 ; 69,4 ; 73,27$ e 76,5, respectivamente), em relação às demais cepas e à não utilização da microbiolização das sementes do hibrido Dardo. Para a cultivar Santa Cruz 47 as rizobactérias LEBM 105, 112 e 152 proporcionaram maiores valores de MFFP (896,7; 769,0 e 762,2 g, respectivamente). Avaliando-se os genótipos ao utilizar cada rizobactéria, para as variáveis MFFP e PDT, verificou-se que apenas para a rizobactéria LEBM 105, não houve diferenças entre os genótipos. Conclui-se, que a microbiolização de sementes de quiabo com rizobactérias pode proporcionar ganhos de produtividade e com potencial de se tornar uma técnica viável. As rizobactérias mais recomendadas para o cultivo do híbrido Dardo são a LEBM 109, 112, 152 e 154, enquanto para o cultivo da cv. Santa Cruz 47 são as cepas LEBM 105, 112 e 152.

Palavras-chave: Abelmoschus esculentus, microorganismo da rizosfera, genótipos de quiabo.

Received on October 23, 2015; accepted on January 23, 2017

$\mathrm{O}$ $\mathrm{kra}$ (Abelmoschus esculentus) is an annual vegetable crop, with excellent nutritional value, rich in vitamins $A$ and $C$, calcium, fibers, niacin, besides having medicinal properties (FAO, 2003). It is especially grown by family farming, since it is a plant which shows a fast vegetative cycle, resistance to pests and diseases and with low-cost production; it is widely cultivated in Brazil, where the weather conditions are excellent for the plant development
(Mota et al., 2010).

However, this crop still does not express its total production potential due to, mainly, the low level of technology adopted by the majority of producers. Thus, the plant-growth promoting 
rhizobacteria (PGPR) can be an alternative to increase the productivity, adding value to the production system.

PGPRs can increase the plant growth since they promote the mineralization of nutrients, by the solubilization of mineral phosphates and the production of growth hormones such as auxins and gibberellins. Besides, the production of low-cost inoculants with PGPRs is an alternative to reduce the use of agrochemicals and chemical products (Coelho et al., 2007). In addition to these benefits, the rhizobacteria can act as biological control agents of diseases (Zhuang et al., 2007). PGPRs act as biological control agents of diseases, since they induce systemic resistance in plants, producing antibiotics and siderophores, which inhibit the growth of several pathogens by activating the formation of physical and chemical barriers (Kloepper et al., 2004; Romeiro, 2007).

Some species of plants have been frequently studied in relation to the effect of the rhizobacteria, like pumpkin (Chen et al., 2000), wheat (Luz, 2001), beet (Cakmakci et al., 2006), eucalyptus (Mafia et al., 2009), onion (Harthmann et al., 2009, 2010) and tomato (Araújo \& Marchesi, 2009).

In Brazilian literature no information on the use and influence of rhizobacteria on okra crop was found. Thus, the aim of this study was to evaluate the agronomic yield of genotypes of okra, hybrid Dardo and cultivar Santa Cruz 47, after seed microbiolization with rhizobacteria.

\section{MATERIAL AND METHODS}

The experiment was carried out at Horta de Ensino, Pesquisa e Extensão from Universidade Estadual de Montes Claros, municipality of Janaúba, Minas Gerais State, Brazil (15\%47'18”S, $43^{\circ} 18^{\prime} 18^{\prime \prime} \mathrm{W}$, altitude $141 \mathrm{~m}$ ), from September, 2009 to January, 2010. This region is part of the Brazilian semi-arid region, the local climate is Aw (tropical with summer rains), according to Köppen classification (Jacomine et al., 1979). The average annual rainfall is $740 \mathrm{~mm}, 85 \%$ occurring from November to March, with average maximum and minimum temperatures of $32^{\circ} \mathrm{C}$ and $19.5^{\circ} \mathrm{C}$, respectively. The soil in which the experiment was installed is a Fluvic Neosol (Embrapa, 1999).

The authors used seeds of cultivar Santa Cruz 47 and hybrid Dardo, microbiolized with rhizobacteria: LEBM 103, 105, 109, 112, 118, 134, 135, 152 and 154, classified as Bacillus sp., Pseudomonas fluorescens and actinomycetes, isolated and obtained at Laboratory of Epidemiology and Biocontrol of Microorganisms, State University of Montes Claros.

The process of seed microbiolization started with the removal of existing impurities, being immersed in $1 \%$ sodium hypochlorite for 5 minutes and, then, rinsed three times with sterile distilled water. Afterwards, the seeds were dried in a laminar flow chamber, on sterile paper towel, and then they were placed in Erlenmeyer and immersed in $4.68 \mu \mathrm{L}$ of the bacterial suspensions for one hour and under stirring at 150 rpm in the orbital shaker (model 430/ RDBP, Nova Ética). Afterwards, the seeds were dried for 2 hours, similarly to the previous way. Then, the seeds were kept in sterile paper bags and were immediately planted.

The experimental design was completely randomized, arranged in a $2 \times 10$ factorial scheme, two okra genotypes, nine strains of rhizobacteria and one control without microbiolization, with four replications. Each plot was composed of four planting lines, measuring $2 \mathrm{~m}$ long each, spacing $1.0 \times 0.5 \mathrm{~m}$, totalizing 16 plants, with a total area of $8 \mathrm{~m}^{2}$. The area consisted of four central plants, with a total area of $2 \mathrm{~m}^{2}$.

For fertilizer recommendation, a sample composed of soil from $0-20 \mathrm{~cm}$ depth of the experimental area was taken (Ribeiro et al., 1999), which presented the following composition: sand $=71 \%$; silt $=20 \%$; clay $=9 \% ; \mathrm{pH}=6.4 ; \mathrm{MO}=$ $1.2 \mathrm{mg} / \mathrm{kg} ; \mathrm{P}=55.9 \mathrm{mg} / \mathrm{dm}^{3} ; \mathrm{K}=128$ $\mathrm{mg} / \mathrm{dm}^{3} ; \mathrm{Na}=0.1 \mathrm{cmol} / \mathrm{dm}^{3} ; \mathrm{Ca}=4.3$ $\mathrm{cmol}_{\mathrm{c}} / \mathrm{dm}^{3} ; \mathrm{Mg}=1.0 \mathrm{cmol} / \mathrm{dm}^{3} ; \mathrm{Al}=$ $0.0 \mathrm{cmol}_{\mathrm{c}} / \mathrm{dm}^{3} ; \mathrm{H}+\mathrm{Al}=1.3 \mathrm{cmol}_{\mathrm{c}} / \mathrm{dm}^{3}$; $\mathrm{B}=0.3 \mathrm{mg} / \mathrm{dm}^{3} ; \mathrm{Cu}=1.8 \mathrm{mg} / \mathrm{dm}^{3} ; \mathrm{Fe}=$ $49.1 \mathrm{mg} / \mathrm{dm}^{3} ; \mathrm{Mn}=30.6 \mathrm{mg} / \mathrm{dm}^{3} ; \mathrm{Zn}=$ $6.7 \mathrm{mg} / \mathrm{dm}^{3} ; \mathrm{t}=5.7 \mathrm{cmol}_{\mathrm{c}} / \mathrm{dm}^{3} ; \mathrm{T}=7.0$ $\mathrm{cmol}_{\mathrm{c}} / \mathrm{dm}^{3} ; \mathrm{SB}=5.7 \mathrm{cmol}_{\mathrm{c}} / \mathrm{dm}^{3} ; \mathrm{V}=$
$82 \% ; \mathrm{M}=0 \%$.

Okra seeds were planted in tubes of $12 \mathrm{~cm}$ length and $55 \mathrm{~cm}^{3}$, on September 17, 2009, using commercial substrate Plantmax, under greenhouse conditions, until the transplanting, when the seedlings showed two definitive leaves. The transplanting into the experimental area was carried out on October 8, 2009.

Fertilization was carried out according to the soil analysis interpretation, taking as reference Ribeiro et al. (1999). Thus, $30 \mathrm{t} / \mathrm{ha}$ of tanned barnyard manure, $40 \mathrm{~kg} / \mathrm{ha}$ of $\mathrm{P}_{2} \mathrm{O}_{5}, 60 \mathrm{~kg} / \mathrm{ha}$ of $\mathrm{K}_{2} \mathrm{O}$ and $120 \mathrm{~kg} / \mathrm{ha}$ of $\mathrm{N}$ were applied into planting furrows. All of $\mathrm{P}_{2} \mathrm{O}_{5}$ was applied at planting time, whereas $\mathrm{K}_{2} \mathrm{O}$ and $\mathrm{N}$ were splitted, being $40 \%$ of $\mathrm{K}_{2} \mathrm{O}$ and $20 \%$ of $\mathrm{N}$ applied at planting time, and the rest of them $(60 \%$ of $\mathrm{K}_{2} \mathrm{O}$ and $80 \%$ of N) splitted at 20,40 and 60 days after planting.

The seeds were irrigated using a micro-sprinkler system, the management was carried out using a class A evaporation pan, irrigation water depth of $5 \mathrm{~mm} /$ day, being irrigated once daily due to the sandy texture of the soil. No disease incidence or pest attack was observed. The weed control was carried out through hoeing. Okra fruits were harvested every three days, for twelve weeks, when the first fruit showed up, at commercial harvesting time (10 to 12 $\mathrm{cm}$ length), when they were still tender.

After harvesting, the fruits were packed in plastic boxes, and taken to the Laboratory of Post-harvest of State University of Montes Claros, where the analyses were carried out.

The authors analyzed: 1) number of fruits per plant (NFP) (number of fruits of the useful plot divided by number of plants of the useful plot); 2) average diameter of okra fruit (DM) (freshly harvested fruits, measured with the aid of a caliper in the median region of the fruit, the result was expressed in $\mathrm{cm}$ ); 3) fresh mass of fruits per plant (MFFP); 4) average mass of fruit (MMF) (obtained by dividing the fresh mass of fruits of each plot by the number of fruits of their respective plots) and 5) productivity (PDT), which was estimated considering the production of useful area of each plot and plant population density, expressed in $\mathrm{kg} / \mathrm{ha}$. 
The data obtained were submitted to analysis of variance. The effects of cultivars and rhizobacteria were studied by $\mathrm{F}$ test and Tukey test, at 5\% probability, using the statistical program SAEG.

\section{RESULTS AND DISCUSSION}

The agronomic characteristics evaluated were significantly influenced by the use of cultivars and rhizobacteria. Thus, the number of fruits per plant, fruit diameter, productivity, fresh mass of fruits per plant and average mass per fruit showed significant differences for cultivars and rhizobacteria.

When evaluating the effect of microbiolization with rhizobacteria on hybrid Dardo in relation to the control, the authors verified that the use of rhizobacteria LEBM 109, LEBM 112, LEBM 152 and LEBM 154 provided higher values for number of fruits per plant (NFP), fresh mass of fruits per plant (MFFP) and productivity (PDT): LEBM 109 presented values of 24.1 $\mathrm{t} / \mathrm{ha}, 78.04$ and $1202.7 \mathrm{~g}$ for PDT, NFP and MFFP, respectively; LEBM 152 presented values of $23.2 \mathrm{t} / \mathrm{ha}, 73.27$ and $1158.2 \mathrm{~g}$ for PDT, NFP and MFFP, respectively; LEBM 152 presented values of $23.2 \mathrm{t} / \mathrm{ha}, 73.27$ and $1158.2 \mathrm{~g}$ for PDT, NFP and MFFP, respectively; and LEBM 154 presented values of 23.5 t/ha, 76.50 and $1175.9 \mathrm{~g}$ for PDT, NFP and MFFP, respectively (Tables 1 and 2 ). The other rhizobacteria tested did not show significant differences among them and also, in relation to the control, for these variables: In relation to the average diameter (DM) and average mass per fruit (MMF), the effect of microbiolization with rhizobacteria on hybrid Dardo seeds was not noticed (Tables 1 and 2).

The seed microbiolization of cultivar Santa Cruz 47 with rhizobacteria LEBM 105 and 152 provided highest values for NFP, MFFP and PDT and the rhizobacteria LEBM 112 provided highest values for MFFP and PDT compared with the control (Tables 1 and 2). For DM, the rhizobacteria LEBM $103,105,112,118,135,152$ and 154 showed positive effect.

The application of some rhizobacteria on okra provided significantly higher production in relation to control, especially LEBM 109, 112, 152 and 154 on hybrid Dardo, with 19.9, 7.9, 15.4 and $16.9 \%$ more for PDT, respectively; and LEBM 105, 112 and 152 on cultivar Santa Cruz 47, with $68.9,45.3$ and $43.43 \%$, respectively. The ability to stimulate the plant growth showed by rhizobacteria has been attributed to various mechanisms, among these mechanisms, hormone production, and, as a consequence, an increase in development of roots and aboveground area, number of leaves, leaf area and crop yield. If at least one of these modifications is observed, it can be considered as a plant growth promoter (Patten \& Glick, 1996). Thus, rhizobacteria LEBM 105, 109, 112, 152 and 154 can be defined as plant growth promoters. Harthmann et al. (2010) also verified in onions microbiolized with rhizobacteria differences in percentage, compared to the control, ranged from 15.7 to $24.4 \%$ for productivity of bulbs.

For NFP, the authors noticed a significant interaction between genotype and rhizobacteria. Comparing the varieties in each rhizobacteria and the control, the authors noticed that the hybrid Dardo was superior than the cultivar Santa Cruz 47 for all rhizobacterias tested.

When the genotype $\mathrm{x}$ rhizobacteria interaction was unfolded, the authors verified no significant difference for DM among the rhizobacteria on hybrid Dardo. However, the authors noticed significant difference among rhizobacteria on cultivar Santa Cruz 47, in which the rhizobacteria LEBM 103, LEBM 105, LEBM 112, LEBM 118, LEBM 135, LEBM 152 and LEBM 154 showed DM higher than the others (Table 1). The authors also observed that hybrid Dardo was superior to the cultivar Santa Cruz 47 when microbiolized with rhizobacteria LEBM 105, LEBM 109 and LEBM 152,

Table 1. Number of fruits per plant, diameter and productivity of okra fruits of hybrid Dardo and cultivar Santa Cruz 47, according to rhizobacteria. Janaúba, UNIMONTES, 2010.

\begin{tabular}{|c|c|c|c|c|c|c|}
\hline \multirow{2}{*}{ Rhizobacteria } & \multicolumn{2}{|c|}{ Fruits/plant } & \multicolumn{2}{|c|}{ Fruit diameter (cm) } & \multicolumn{2}{|c|}{ Productivity (t/ha) } \\
\hline & Dardo & Santa Cruz 47 & Dardo & Santa Cruz 47 & Dardo & Santa Cruz 47 \\
\hline LEBM 103 & $62.14 \mathrm{aB}$ & $35.42 \mathrm{bB}$ & $1.5 \mathrm{aA}$ & $1.4 \mathrm{aA}$ & $19.9 \mathrm{aB}$ & $11.6 \mathrm{bB}$ \\
\hline LEBM 105 & $64.06 \mathrm{aB}$ & $48.25 \mathrm{bA}$ & $1.4 \mathrm{aA}$ & $1.3 \mathrm{bA}$ & $19.8 \mathrm{aB}$ & $17.9 \mathrm{aA}$ \\
\hline LEBM 109 & $78.04 \mathrm{aA}$ & $39.38 \mathrm{bB}$ & $1.4 \mathrm{aA}$ & $1.2 \mathrm{bB}$ & $24.1 \mathrm{aA}$ & $13.9 \mathrm{bB}$ \\
\hline LEBM 112 & $69.42 \mathrm{aA}$ & $40.88 \mathrm{bB}$ & $1.4 \mathrm{aA}$ & $1.4 \mathrm{aA}$ & $21.7 \mathrm{aA}$ & $15.4 \mathrm{bA}$ \\
\hline LEBM 118 & $61.83 \mathrm{aB}$ & $38.13 \mathrm{bB}$ & $1.4 \mathrm{aA}$ & $1.4 \mathrm{aA}$ & $18.1 \mathrm{aB}$ & $13.2 \mathrm{bB}$ \\
\hline LEBM 134 & $58.83 \mathrm{aB}$ & $37.50 \mathrm{bB}$ & $1.4 \mathrm{aA}$ & $1.3 \mathrm{aB}$ & $16.3 \mathrm{aB}$ & $12.6 \mathrm{bB}$ \\
\hline LEBM 135 & $63.67 \mathrm{aB}$ & $34.00 \mathrm{bB}$ & $1.4 \mathrm{aA}$ & $1.4 \mathrm{aA}$ & $19.1 \mathrm{aB}$ & $11.6 \mathrm{bB}$ \\
\hline LEBM 152 & $73.27 \mathrm{aA}$ & $44.00 \mathrm{bA}$ & $1.5 \mathrm{aA}$ & $1.4 \mathrm{bA}$ & $23.2 \mathrm{aA}$ & $15.2 \mathrm{bA}$ \\
\hline LEBM 154 & $76.50 \mathrm{aA}$ & $39.88 \mathrm{bB}$ & $1.4 \mathrm{aA}$ & $1.4 \mathrm{aA}$ & $23.5 \mathrm{aA}$ & $13.4 \mathrm{bB}$ \\
\hline Control & $67.17 \mathrm{aB}$ & $31.96 \mathrm{bB}$ & $1.4 \mathrm{aA}$ & $1.2 \mathrm{bB}$ & $20.1 \mathrm{aB}$ & $10.6 \mathrm{bB}$ \\
\hline CV (\%) & \multicolumn{2}{|c|}{10.31} & \multicolumn{2}{|r|}{4.30} & \multicolumn{2}{|r|}{12.15} \\
\hline
\end{tabular}

Averages followed by the same lowercase letters in lines for each characteristic and uppercase letter in the column did not differ significantly, at $5 \%$ probability, Tukey test. 
and also on the control (Table 1). When microbiolized with the other rhizobacteria, LEBM 103, 112, 118, 134,135 , and 154, the genotypes did not differ among them. Probably, these rhizobacteria showed higher degree of interaction with the cultivar Santa Cruz 47 , resulting in beneficial effect on the plant development (Moreira \& Siqueira, 2006). The diameter values ranged from 1.4 to $1.50 \mathrm{~cm}$ in hybrid Dardo and from 1.2 to $1.4 \mathrm{~cm}$ in cultivar Santa Cruz 47 . These values are within the range found by Mota et al. (2005), which was from 1.4 to $3.3 \mathrm{~cm}$, and by Guimarães (2008), who obtained average values of $1.5 \mathrm{~cm}$ for diameter of okra, evaluating the agronomic yield of okra and onion in consortium and monoculture.

Evaluating PDT, the authors verified in unfolding between genotypes and rhizobacteria that the rhizobacteria LEBM 109, 112, 152 and 154 provided highest PDT in hybrid Dardo (Table 1). In cultivar Santa Cruz 47, the rhizobacteria LEBM 105, 112 and 152 influenced higher average values in relation to the others $(17.9,15.4$ and $15.2 \mathrm{t} / \mathrm{ha}$, respectively). The average values for PDT provided by the other rhizobacteria ranged from 11.6 to 13.9 t/ha for cultivar Santa Cruz 47 (Table 1). Probably, these more efficient rhizobacteria showed higher degree of interaction, resulting in beneficial effects on plant development (Moreira \& Siqueira, 2006). When the authors analyzed the averages for PDT of the genotypes in each rhizobacteria, no superiority of hybrid Dardo was observed, only for LEBM 105.

When evaluating MFFP for hybrid Dardo, the authors noticed that LEBM 109, 112, 152 and 154 showed highest averages (Table 2). In cultivar Santa Cruz 47, the rhizobacteria which provided highest averages for MFFP were LEBM 105, 112 and 152, whose averages were 896.7, 769.0, $762.2 \mathrm{~g}$, respectively. The values for MFFP provided by the rhizobacteria on cultivar Santa Cruz 47 ranged from 577.5 to $896.7 \mathrm{~g}$ (Table 2). Evaluating genotypes within each rhizobacteria, no difference was verified, only for rhizobacteria LEBM 105 (Table 2), considering that the other rhizobacteria, and in the control, hybrid Dardo and cultivar Santa Cruz 47, as expected, since the hybrids presents, genetically, higher vigor, which determines higher productions and productivities when compared to cultivars (Cavalcante et al., 2003).

For MMF, the authors observed after unfolding genotype $\mathrm{x}$ rhizobacteria interaction that, for hybrid Dardo, the rhizobacteria did not differ among each other, showing values from 13.3 to 15.5 g. In cultivar Santa Cruz, higher averages for MMF in treatments LEBM

Table 2. Average values of fresh mass of fruits per plant and average mass per okra fruit of hybrid Dardo and cultivar Santa Cruz 47 according to. Janaúba, UNIMONTES, 2010.

\begin{tabular}{|c|c|c|c|c|}
\hline \multirow[t]{2}{*}{ Rhizobacteria } & \multicolumn{2}{|c|}{$\begin{array}{c}\text { Fresh mass of fruits/ } \\
\text { plant (g) }\end{array}$} & \multicolumn{2}{|c|}{$\begin{array}{c}\text { Average mass/fruit } \\
\text { (g) }\end{array}$} \\
\hline & Dardo & Santa Cruz 47 & Dardo & Santa Cruz 47 \\
\hline LEBM 103 & $996.1 \mathrm{aB}$ & $577.5 \mathrm{bB}$ & $15.5 \mathrm{aA}$ & $14.3 \mathrm{aB}$ \\
\hline LEBM 105 & $991.5 \mathrm{aB}$ & $896.7 \mathrm{aA}$ & $13.8 \mathrm{aA}$ & $15.6 \mathrm{aB}$ \\
\hline LEBM 109 & $1202.7 \mathrm{aA}$ & $697.4 \mathrm{bB}$ & $14.7 \mathrm{aA}$ & $13.4 \mathrm{aC}$ \\
\hline LEBM 112 & $1086.5 \mathrm{aA}$ & $769.0 \mathrm{bA}$ & $14.6 \mathrm{bA}$ & $16.6 \mathrm{aA}$ \\
\hline LEBM 118 & $902.9 \mathrm{aB}$ & $660.0 \mathrm{bB}$ & $13.5 \mathrm{bA}$ & $15.3 \mathrm{aB}$ \\
\hline LEBM 134 & $815.2 \mathrm{aB}$ & $631.7 \mathrm{bB}$ & $13.3 \mathrm{aA}$ & $12.3 \mathrm{aC}$ \\
\hline LEBM 135 & $955.5 \mathrm{aB}$ & $581.1 \mathrm{bB}$ & $14.5 \mathrm{aA}$ & $14.8 \mathrm{aB}$ \\
\hline LEBM 152 & $1158.2 \mathrm{aA}$ & $762.2 \mathrm{bA}$ & $14.6 \mathrm{bA}$ & $16.6 \mathrm{aA}$ \\
\hline LEBM 154 & $1175.9 \mathrm{aA}$ & $670.9 \mathrm{bB}$ & $15.1 \mathrm{aA}$ & $14.5 \mathrm{aB}$ \\
\hline Control & $1007.3 \mathrm{aB}$ & $528.7 \mathrm{bB}$ & $14.2 \mathrm{aA}$ & $12.7 \mathrm{aC}$ \\
\hline CV (\%) & \multicolumn{2}{|c|}{12.15} & \multicolumn{2}{|c|}{8.36} \\
\hline
\end{tabular}

Averages followed by the same lowercase letters in lines for each characteristic and uppercase letter in the column did not differ significantly, at 5\% probability, Tukey test.
112 and 152 were verified (Table 2). The averages for MMF in cultivar Santa Cruz 47 ranged from 12.3 to $16.6 \mathrm{~g}$ (minimum and maximum values, respectively). Similar results in relation to MMF were found by Ribas et al. (2002, 2003), considering that values for MMF of okra, in several production systems, ranged from 14.7 to $14.8 \mathrm{~g}$. These values are also within the range found by Mota et al. (2005), which was of 9.4 to $37.5 \mathrm{~g}$, for MMF. Among the genotypes, cultivar Santa Cruz 47 showed the highest averages for MMF with rhizobacteria LEBM 112, 118 and 152 , not showing any significant difference in the other rhizobacteria (Table 2). Thus, these rhizobacteria made MMF of cultivar Santa Cruz 47 higher in relation to hybrid Dardo.

The authors concluded that okra seed microbiolization with rhizobacteria is able to provide productivity gains. For hybrid Dardo, the most recommended rhizobacteria are LEBM 109, 112, 152 and 154, whereas for cultivar Santa Cruz 47 , the most recommended rhizobacteria are 105,112 and 152 .

\section{ACKNOWLEDGEMENTS}

The authors thank UNIMONTES for the support of this research and FAPEMIG for Research Incentive and Technological Development of Minas Gerais State scholarship granted to the second author.

\section{REFERENCES}

ARAÚJO, FF; MARCHESI, GVP. 2009. Uso de Bacillus subtilis no controle da meloidoginose e na promoção do crescimento do tomateiro. Ciência Rural 39: 1558-1561.

CAKMAKCI, R; DÖNMEZ, F; AYDIN, A; SAHIN, F. 2006. Growth-promoting rhizobacteria under greenhouse and two different field soil conditions. Soil Biology and Biochemistry 38: 1482-1487.

CAVALCANTE, JJV; CRISÓSTOMO, JR; BARROS, LM; PAIVA, JR. 2003. Heterose em cajueiro anão precoce. Ciência $e$ Agrotecnologia 27: 565-570.

CHEN, C; BÉLANGER, RR; BENHAMOU, N; PAULITZ, TC. 2000. Defense enzymes induced in cucumber roots by treatment with plant growth-promoting rhizobacteria (PGPR) 
and Pythium aphanidermatu. Physiology Molecular 56: 13-23.

COELHO, LF; FREITAS, SS; MELO, AMT; AMBROSANO, GMV. 2007. Interação de bactérias fluorescentes do gênero Pseudomonas e de Bacillus spp. com a rizosfera de diferentes plantas. Revista Brasileira de Ciência do Solo 31: 1413-1420.

EMBRAPA. Centro Nacional de Pesquisa de Solos. 1999. Sistema Brasileiro de Classificação de Solos. Rio de Janeiro: Embrapa Solos. 412p.

FAO. 2003. Melhorar a nutrição através das hortas familiares. Roma: FAO. 297p. Disponível em: http://www.fao.org/docrep/007/x3996p/ x3996p18.htm Acessado em 25 de junho de 2015.

GUIMARÃES, AFR. 2008. Rendimento agronômico de quiabo e cebola em consórcio e monocultivo. Janaúba: UNIMONTES. 57p. (Tese mestrado).

HARTHMANN, OEL; MÓGOR, AF; WORDELL FILHO, JA; LUZ, WC. 2010. Rizobactérias no crescimento e na produtividade da cebola. Ciência Rural 40: 462-465.

HARTHMANN, OEL; MÓGOR, AF; WORDELL FILHO, JA; LUZ, WC; BIASI, LA. 2009. Tratamento de sementes com rizobactérias na produção de cebola. Ciência Rural 39: 2533-2538.

JACOMINE, PKT; CAVALCANTI, AC;
FORMIGA, RA; SILVA, FBR; BURGOS, N; MEDEIROS, LAR; LOPES, OP; MELO FILHO, HRL; PESSOA, SGP; LIMA, PC. 1979. Levantamento exploratórioreconhecimento de solos do Norte de Minas Gerais (área de atuação da SUDENE). Recife: EMBRAPA/SNLCS-SUDENE. 407p. (Boletim Técnico, 60).

KLOEPPER, JW; RYU, CM; ZHANG, SA. 2004. Induced systemic resistance and promotion of plant growth by Bacillus spp. Phytopathology 94:1259-1266.

LUZ, WC. 2001. Evaluation of plant growthpromoting and bioprotecting rhizobacteria on wheat crop. Fitopatologia Brasileira 26: 597-600.

MAFIA, RG; ALFENAS, AC; MAFFIA, LA; FERREIRA, EM; BINOTI, DHB; SIQUEIRA, L. 2009. Microbiolização e interação entre rizobactérias promotoras do crescimento e clones de eucalipto. Árvore 33: 789-797.

MOREIRA, FMS; SIQUEIRA, JO. 2006. Microbiologia e Bioquimica do Solo. 2. ed. atual. e ampl. Lavras: UFLA. 729p.

MOTA, WF; FINGER, FL; CECON, PR; SILVA, DJH; CORRÊA, PC; FIRME, LP; MIZOBUTSI, GP. 2010. Conservação e qualidade pós-colheita de quiabo sob diferentes temperaturas e formas de armazenamento. Horticultura Brasileira 28: 12-18.

MOTA, WF; FINGER, FL; SILVA, DJH;
CORRÊA, PC; FIRME, LP; NEVES, LLM. 2005. Caracterização físico-química de frutos de quatro cultivares de quiabo. Horticultura Brasileira.23: 722-725.

PATTEN, C; GLICK, BR. 1996. Bacterial biosynthesis of indole-3-acetic acid. Canadian Journal of Microbiology 42: 207-220.

RIBAS, RGT; JUNQUEIRA, RM; OLIVEIRA, FL; GUERRA, JGM; ALMEIDA, DL; ALVES, BJR; RIBEIRO, RLD. 2003. Desempenho do quiabeiro (Abelmoschus esculentus) consorciado com Crotalaria juncea sob manejo orgânico. Agronomia 37: 80-84.

RIBAS, RGT; JUNQUEIRA, RM; OLIVEIRA, FL; GUERRA, JGM; ALMEIDA, DL; RIBEIRO, RLD. 2002. Adubação verde na forma de consórcio no cultivo do quiabeiro sob manejo orgânico. Seropédica: EMBRAPA. (Comunicado Técnico, 54).

RIBEIRO, AC; GUIMARÃES, PTG; ALVAREZ, V.1999. Recomendações para o uso de corretivos efertilizantes em Minas Gerais. 5 a aproximação. Viçosa: UFV. 359p.

ROMEIRO, RS. 2007. Controle biológico de doenças de plantas - Fundamentos. Viçosa: UFV. 296p.

ZHUANG, X; CHEN, J; SHIM, H; BAI, Z. 2007. New advances in plant growth-promoting rhizobacteria for bioremediation. Environment International 33: 406-413. 